\title{
Analysis of student needs in writing French languages elementary levels based on blended learning in disruption era
}

\author{
Dwi Astuti $^{1}$, Subyantoro ${ }^{2}$, Ida Zulaeha ${ }^{3}$, Astini Su' $^{\prime}$ udi $^{4}$, Novi Kurniawati ${ }^{5}$ \\ astutidwi@mail.unnes.ac.id', bintoro@mail.unnes.ac.id², idazulaeha@mail.unnes.ac.id ${ }^{4}$, \\ ediastini@gmail.com ${ }^{4}$, novikurniawati@mail.unnes.ac.id ${ }^{5}$
}

Universitas Negeri Semarang, Faculty of languages and arts, - Indonesia ${ }^{1}$, Universitas Negeri Semarang, Graduate School,-Indonesia ${ }^{2}$, Universitas Negeri Semarang, Graduate School, - Indonesia ${ }^{3}$, Universitas Negeri Semarang, Graduate School, - Indonesia ${ }^{4}$, Universitas Negeri Semarang, Faculty of languages and arts, - Indonesia ${ }^{5}$

\begin{abstract}
Semarang State University as one of the universities in Indonesia has quickly responded to the era of disruption by implementing Blended Learning, one of them in the Production Écrite Élémentaire course. However, the learning content in these activities has not been fully prepared. This research aims to describe the needs of students in Frenchlanguage writing at the level of elementary based on blended learning in the era of disruption. This study produced data on the needs of students in French writing which included: writing themes, types of activity support, ways of delivering material, online interaction media, and learning strategies. This data can be used to develop a French language learning model at the level of elementary based on blended learning.
\end{abstract}

Keywords: student needs analysis, writing level elementary, blended learning

\section{Introduction}

Semarang State University as one of the universities in Indonesia has quickly responded to the era of disruption by implementing Blended Learning, one of them in the Production Écrite Élémentaire course. However, the learning content in these activities has not been fully prepared. For this reason, a study of the needs of students in these courses is needed to equip students to compete in the job market.

Research on needs analysis has been carried out by many previous researchers, including the analysis of the needs of teaching materials [1], [2]. In other studies, Lestari [3], Nurhidayah [4], and Dja'far [5] examined needs analysis in teaching and learning, while Thaib [6] and Priwantoro [7] examined the analysis of development needs, and finally, Rahmi [8], Setiyaningrum [9], and Kurniawan [10] examined the analysis of student needs.

These studies focus on needs analysis, but differ from what will be done by researchers. The needs analysis that has been carried out is about the needs analysis of teaching materials, needs analysis on teaching and learning, and needs analysis of the other learning support development. The analysis of student needs that have been carried out is not related to French, while what will be done is the student's need for French-language skills at the elementary level. 
Regarding the French language, Mutiarsih [11], Yuliarti [12], and Hasanah [13]have conducted research that highlights French language learning, but none has been related to analyzing the needs of students in writing in French.

In terms of applying blended learning, several studies have also been conducted [14], [15]but the blended learning was not applied to learning French writing.

Brown [16] defines needs analysis as an activity of identifying the language elements needed by students when they are required to understand and use the target language. In this case the student needs include material, how to deliver material, online interaction media, and learning strategies.

In learning French, the French Language Education program, Semarang State University refers to Le Cadre Européen Commun de Référence pour les Langues (CECRL ). With this reference, Conseil de 1 'Europe [17] states that globally the level of language learning is divided into three, namely: the basic level (niveau de base / élémentaire), intermediate level (niveau intermédiaire), and advanced level (niveau avancé). The elementary level consists of two, namely: A1 and A2.

Vigner [18] explains in detail the activities in writing that must be mastered by language learners at levels $\mathrm{A} 1$ and $\mathrm{A} 2$ as follows.

Table 1. Description of activity writes levels A1 and A2

\begin{tabular}{cl}
\hline Niveau & Activités \\
\hline A1 & $\begin{array}{l}\text { Je peux écrire une carte postale simple. } \\
\text { Je peux porter des détails personnels dans un questionnaire, inscrire. }\end{array}$ \\
A2 & $\begin{array}{l}\text { Je peux écrire des notes et messages simples et courts. } \\
\text { Je peux écrire une lettre personnelle très simple. }\end{array}$ \\
\hline
\end{tabular}

Furthermore, Tagliante [19] describes the types of activity support that can be used in writing skills levels A1 and A2 as follows.

Table 2. Activity support types that can be used at A1 and A2 level

\begin{tabular}{cl}
\hline Niveau & Types de support d'activités \\
\hline A1 & Petites lettre personnelles \\
& Messages informels \\
& Courriels \\
& Agendas, emplois du temps \\
& Cartes diverses ( anniversaires, voeux, mariages, invitations...) \\
& Formulaires et fiches à compléter \\
A2 & Lettres personnelles \\
& Courriers administratifs \\
& Messages pris lors d'une conversation, en présentiel ou au telephone
\end{tabular}

These materials must be in accordance with the needs of students in this all-digital disruption era. One of the digital-based learning models that can be applied is blended learning, namely combination learning between face-to-face, computer-based learning (offline), and internet-based learning (online) ( [20], [21]). In addition, in studying the material, it is also necessary to pay attention to the learning strategies that can be used by students, one of which was put forward by Oxford and translated by Syaefudin [22] which includes: remembering 
strategies, cognitive strategies, supporting strategies, meta-cognitive strategies, affective strategies and socio-affective strategies.

This research aims to describe the needs of students in French-language writing at the level of elementary based on blended learning in the era of disruption. This data can be used to develop a French language learning model at the level of elementary based on blended learning.

\section{Method}

This research is an explorative descriptive study with students of the French Language Education Program, Semarang State University in the year 2018 with a total of 43. Data collection in this study was conducted using a questionnaire method to obtain data on the needs of students in French-language writing at the level of elementary based on blended learning. Data retrieval was carried out on July 11, 2019. The collected data were analyzed using percentage descriptive analysis.

\section{Results and Discussion}

Generally, the needs of students in French-language writing at the level of elementary in this study include four things, namely material, how to deliver material, online interaction media, and learning strategies. The material in French language writing at the level of elementary refers to Le Cadre Europen Commun de Référence pour les Langues (CECRL). With this reference, the level of elementary consists of two, namely levels A1 and A2. The results of the needs analysis in terms of material level A1 are shown in table 3.

Table 3. Needs to write level A1

\begin{tabular}{|c|c|c|c|c|c|c|c|}
\hline No & $\begin{array}{l}\text { Writing } \\
\text { activity }\end{array}$ & Themes / Activities & $\begin{array}{l}\text { Number } \\
\text { of voters }\end{array}$ & Percentage & $\begin{array}{l}\text { Type of } \\
\text { support }\end{array}$ & $\begin{array}{l}\text { Number } \\
\text { of } \\
\text { voters }\end{array}$ & Percentage \\
\hline \multirow[t]{5}{*}{1} & \multirow[t]{5}{*}{$\begin{array}{l}\text { I can write a } \\
\text { simple } \\
\text { postcard }\end{array}$} & holiday & 32 & $74 \%$ & $\begin{array}{l}\text { Short } \\
\text { personal } \\
\text { letter }\end{array}$ & 33 & $77 \%$ \\
\hline & & your studies & 15 & $35 \%$ & $\begin{array}{l}\text { Informal } \\
\text { messages }\end{array}$ & 19 & $44 \%$ \\
\hline & & anniversary & 23 & $53 \%$ & emails & 30 & $70 \%$ \\
\hline & & & & & $\begin{array}{l}\text { Diaries, time } \\
\text { tables }\end{array}$ & 15 & $35 \%$ \\
\hline & & & & & Various cards & 20 & $47 \%$ \\
\hline \multirow[t]{4}{*}{2} & \multirow{4}{*}{$\begin{array}{l}\text { I can carry } \\
\text { personal } \\
\text { details in a } \\
\text { questionnaire, } \\
\text { register }\end{array}$} & $\begin{array}{l}\text { Complete the form to } \\
\text { stay at the hôtel }\end{array}$ & 24 & $56 \%$ & $\begin{array}{l}\text { Forms to } \\
\text { complete }\end{array}$ & 39 & $91 \%$ \\
\hline & & $\begin{array}{l}\text { Complete the registration } \\
\text { form as a member of the } \\
\text { library }\end{array}$ & 16 & $37 \%$ & $\begin{array}{l}\text { Cards to } \\
\text { complete }\end{array}$ & 16 & $37 \%$ \\
\hline & & $\begin{array}{l}\text { Complete the entry form } \\
\text { for a course }\end{array}$ & 27 & $63 \%$ & & & \\
\hline & & $\begin{array}{l}\text { Complete the passport } \\
\text { making form }\end{array}$ & 28 & $65 \%$ & & & \\
\hline
\end{tabular}


In table 3, it can be seen that in writing 'I can write a simple postcard', the theme / activity most needed by students is holiday, followed by anniversary and your studies. The types of support activities needed by students are short personal letter, emails, various cards, informal messages, diaries, and time tables. In the activity of 'I can carry personal details in a questionnaire, register', students need activities complete the passport making form, complete the entry form for a course, complete the form to stay at the hotel, and complete the registration form as a member of the library. In this activity, the type of support needed by students is Forms to complete and Cards to complete. The results of the needs analysis in terms of material level A2 are shown in table 4.

Table 4. Needs to write level A2

\begin{tabular}{|c|c|c|c|c|c|c|c|}
\hline No & $\begin{array}{l}\text { Writing } \\
\text { activity }\end{array}$ & $\begin{array}{l}\text { Themes / } \\
\text { Activities }\end{array}$ & $\begin{array}{l}\text { Numb } \\
\text { er of } \\
\text { voters }\end{array}$ & $\begin{array}{l}\text { Percentag } \\
\mathrm{e}\end{array}$ & Type of support & $\begin{array}{l}\text { Number } \\
\text { of } \\
\text { voters }\end{array}$ & $\begin{array}{l}\text { Percentag } \\
\text { e }\end{array}$ \\
\hline \multirow[t]{3}{*}{1} & $\begin{array}{l}\text { I can write } \\
\text { simple and } \\
\text { short notes }\end{array}$ & Event & 22 & $51 \%$ & $\begin{array}{l}\text { Messages taken } \\
\text { during a face-to- } \\
\text { face conversation }\end{array}$ & 29 & $67 \%$ \\
\hline & and & A past activity & 26 & $60 \%$ & Messages taken & 26 & $60 \%$ \\
\hline & messages & $\begin{array}{l}\text { A personal } \\
\text { experience }\end{array}$ & 32 & $74 \%$ & $\begin{array}{l}\text { during a } \\
\text { conversation by } \\
\text { the phone }\end{array}$ & & \\
\hline \multirow[t]{3}{*}{2} & I can write a & Express thanks & 23 & $53 \%$ & Personal letters & 38 & $88 \%$ \\
\hline & very simple & Express excuses & 19 & $44 \%$ & & & \\
\hline & $\begin{array}{l}\text { personal } \\
\text { letter }\end{array}$ & $\begin{array}{l}\text { Take a short and } \\
\text { simple message }\end{array}$ & 35 & $81 \%$ & $\begin{array}{l}\text { Administrative } \\
\text { mail }\end{array}$ & 10 & $23 \%$ \\
\hline
\end{tabular}

Based on table 4, it can be seen that in 'I can write simple and short notes and messages' activities, students need themes about a personal experience, a past activity, and an event, while the types of support needed are messages taken during a face-to-face conversation and messages taken during a conversation by the phone. The types of activities needed by students in the activity of 'I can write a very simple personal letter' are take a short and simple message, express thanks, and express excuses. Personal letters and administrative mail are the kind of support students need in writing French in this activity.

The collected data regarding the needs of students on how to deliver material in Frenchlanguage writing at the level of elementary based on blended learning is presented in table 5 .

Table 5. How to deliver material

\begin{tabular}{llll}
\hline No & Option & Number of voters & Percentage \\
\hline 1 & Online 30\%, Offline 30\%, and Face to Face 40\% & 31 & $78 \%$ \\
2 & Online 30\%, Offline 40\%, and Face to Face 30\% & 3 & $7 \%$ \\
3 & & 4 & $9 \%$ \\
4 & Online 40\%, Offline 30\%, and Face to Face 30\% & 5 & $12 \%$ \\
& Others... & \\
\hline
\end{tabular}

Referring to table 5 , it can be seen that the most needed option for students is Online $30 \%$, Offline $30 \%$, and Face to Face $40 \%$. From this data it can be seen that by using blended learning, which combines online, offline and face-to-face teaching, students still need the most face-toface teaching. This is reinforced by the choice of 5 (five) respondents in the other option. They 
want face-to-face teaching as much as 90\% (1 respondent), 70\% (1 respondent), 60\% (1 respondent), and $50 \%$ ( 2 respondents).

The description of the online interaction media needed by students in French-language writing at the level of elementary based on blended learning is presented in table 6 .

Table 6. Online interaction media

\begin{tabular}{llll}
\hline No & Option & Number of voters & Percentage \\
\hline 1 & E-mail & 32 & $74 \%$ \\
2 & Facebook & 2 & $5 \%$ \\
3 & Instagram & 11 & $26 \%$ \\
4 & Youtube & 19 & $44 \%$ \\
5 & WhatsApp & 32 & $74 \%$ \\
\hline
\end{tabular}

In table 6 , it can be seen that the online interaction media that is most needed by students in French-speaking level of elementary based on blended learning is E-mail and WhatsApp. This can be understood because the two media are very close to student life.

In addition to learning material, how to deliver material, and online interaction media, it is also important to know the needs of students about learning strategies. Data on this matter can be seen in table 7 .

The data in table 5 shows that students need both direct and indirect strategies with varying percentages. This implies that in teaching French-language writing at the level of elementary, the lecturer should use variations in the learning strategies used. Therefore the learning strategies needed by students can be realized.

In detail, the needs of student learning strategies are as follows. First, in the remembering strategy, students need more options to group words by type and use images. Second, in cognitive strategies, students need more options of trying to write using sentence patterns that have been learned and trying to translate according to context, not words. Third, in supporting strategies, students need more options. Using general knowledge to guess unknown French meanings and using Indonesian when not knowing a word or phrase in French. This finding is in accordance with the results of a study conducted by Giroux [23] that in order to overcome the limitations of knowledge in the target language, learners sometimes use mother tongue.

Fourth, in the metacognitive strategy, students need more options to develop vocabulary that may be needed and pay attention to mistakes made when writing and use it to correct errors. Fifth, in the affective strategy, students need more options. Encourage themselves to write French and give positive statements to themselves. Sixth, in the socio-affective strategy, students need more options of practicing writing to friends and asking fellow French learners to correct the writing. This is consistent with Wang's [24] findings that students need to work together with their friends or other people because cooperative learning enables learners to improve the quality of their writing. 
Table 7. Learning strategies

\begin{tabular}{|c|c|c|c|c|}
\hline No & Strategy & Option & $\begin{array}{l}\text { Number of } \\
\text { voters }\end{array}$ & Percentage \\
\hline \multirow[t]{6}{*}{1} & \multirow[t]{6}{*}{ Memory } & Grouping words by type & 31 & $72 \%$ \\
\hline & & Grouping words based on synonyms & 22 & $51 \%$ \\
\hline & & Grouping words based on antonyms & 23 & $53 \%$ \\
\hline & & Using new words or phrases in sentences & 26 & $60 \%$ \\
\hline & & Using images & 31 & $72 \%$ \\
\hline & & $\begin{array}{l}\text { Linking French words to other words whose } \\
\text { writing is like French }\end{array}$ & 20 & $47 \%$ \\
\hline \multirow[t]{5}{*}{2} & \multirow[t]{5}{*}{ Cognitive } & Write French words several times & 27 & $63 \%$ \\
\hline & & $\begin{array}{l}\text { Try writing to use sentence patterns that have } \\
\text { been learned }\end{array}$ & 35 & $81 \%$ \\
\hline & & $\begin{array}{l}\text { Try to translate according to context, not } \\
\text { words }\end{array}$ & 34 & $79 \%$ \\
\hline & & $\begin{array}{l}\text { Make a summary of the material being } \\
\text { studied }\end{array}$ & 22 & $51 \%$ \\
\hline & & Use the key words that will be used to write & 28 & $65 \%$ \\
\hline \multirow[t]{4}{*}{3} & \multirow[t]{4}{*}{ Support } & $\begin{array}{l}\text { Use general knowledge to guess unknown } \\
\text { French meanings }\end{array}$ & 33 & $77 \%$ \\
\hline & & $\begin{array}{l}\text { Use Indonesian when you don't know a word } \\
\text { or phrase in French }\end{array}$ & 26 & $60 \%$ \\
\hline & & $\begin{array}{l}\text { Ask someone for help completing the writing } \\
\text { when they find it difficult to complete it }\end{array}$ & 22 & $51 \%$ \\
\hline & & Avoid certain topics & 7 & $16 \%$ \\
\hline \multirow[t]{6}{*}{4} & \multirow[t]{6}{*}{ Metacognitive } & Develop vocabulary that might be needed & 33 & $77 \%$ \\
\hline & & $\begin{array}{l}\text { Linking the topic being discussed with } \\
\text { material that is already known }\end{array}$ & 25 & $58 \%$ \\
\hline & & $\begin{array}{l}\text { Pay attention to mistakes made when writing } \\
\text { and use them to correct errors }\end{array}$ & 33 & $77 \%$ \\
\hline & & $\begin{array}{l}\text { Finding out good ways to learn French } \\
\text { writing }\end{array}$ & 25 & $58 \%$ \\
\hline & & $\begin{array}{l}\text { Search and learn to write to people who are } \\
\text { considered smarter }\end{array}$ & 24 & $56 \%$ \\
\hline & & Evaluating progress in writing French & 29 & $67 \%$ \\
\hline \multirow[t]{4}{*}{5} & \multirow[t]{4}{*}{ Affective } & Give positive statements to yourself & 25 & $58 \%$ \\
\hline & & Encourage yourself to write French & 36 & $84 \%$ \\
\hline & & $\begin{array}{l}\text { Feel proud of yourself when you can write } \\
\text { French well }\end{array}$ & 24 & $56 \%$ \\
\hline & & Write a diary using French & 12 & $28 \%$ \\
\hline \multirow[t]{3}{*}{6} & \multirow[t]{3}{*}{ Socio Affective } & $\begin{array}{l}\text { Asking fellow learners of French to correct } \\
\text { the writing }\end{array}$ & 31 & $72 \%$ \\
\hline & & Practice writing to friends & 36 & $84 \%$ \\
\hline & & Trying to learn about French culture & 22 & $51 \%$ \\
\hline
\end{tabular}




\section{Conclusion}

This study produced data on the needs of students in French language writing at the level of elementary based on blended learning in the era of disruption, which included: material, how to deliver material, online interaction media, and learning strategies. With this data, a learning model for French language writing at the level of elementary can be made that is really needed by students as a means of entering the workforce in the era of disruption. 


\section{References}

[1] A. Dimas, Cari, Suparmi, Sarwanto and J. Handika, "Profil Analisis Kebutuhan Bahan Ajar Mahasiswa Materi Dinamika Gerak Pada Mata Kuliah Fisika Dasar," in Seminar Nasional Fisika dan Aplikasinya, Surakarta, 2016.

[2] M. S. M. B. Bilah, A. Gofur and S. R. Lestari, "Analisis Kebutuhan Bahan Ajar Handout Berdasarkan Model Pengembangan ADDIE untuk Mata Kuliah Anatomi Fisiologi Manusia pada Mahasiswa S1 Pendidikan Biologi Universitas Jember," in Seminar Pendidikan IPA, Malang, 2017.

[3] A. R. E. Lestari, "Analisis Kebutuhan terhadap Pembelajaran Bahasa Inggris Berbasis Karakter," DEIKSIS, vol. 06, pp. 153-228, 2014.

[4] F. Nurhidayah, S. Zubaidah and H. Kuswantoro, "Analisis Kebutuhan Worksheet untuk Pembelajaran Berbasis Masalah di SMKN 2 Batu," Jurnal Pendidikan, vol. 1, no. Teori, Penelitian, dan Pengembangan, pp. 1224-1228, 2016.

[5] V. H. Dja'far, "Analisis Kebutuhan pada Pengajaran Bahasa Inggris di PG-PAUD," Jurnal PG-PAUD Trunojoyo, vol. 4, pp. 82-93, 2017.

[6] D. Thaib, D. Wahyudin, Y. Rahmawati and C. Riyana, "Studi Analisis Kebutuhan terhadap Pengembangan Model Blended Learning pada Sistem Pendidikan Jarak Jauh untuk Meningkatkan Kompetensi Lulusan," EduHumaniora, vol. 8, pp. 107-125, 2016.

[7] S. W. Priwantoro, S. Fahmi and D. Astuti, "Analisis Kebutuhan Pengembangan Multimedia Berbasis Kvisoft Dipadukan dengan Geogebra pada Mata Kuliah Program Linier," AdMathEdu, vol. 8, pp. 49-54, 2018.

[8] Rahmi, A. Mardiyah and R. Juwita, "Analisis Kebutuhan Mahasiswa dalam Mengikuti Perkuliahan Aljabar Linear Elementer," LEMMA, vol. 3, pp. 1-7, 2017.

[9] L. Setiyaningrum, S. P. Arso and E. Y. Fatmasari, "Analisis Kebutuhan (Need) Mahasiswa terhadap Pelayanan Kesehatan Kampus Universitas Diponegoro," Jurnal Kesehatan Masyarakat, vol. 5, pp. 69-75, 2017.

[10] W. Kurniawan, F. B. Pujaningsih, Alrizal and N. A. Latifah, "Analisis Kebutuhan Mahasiswa terhadap Bahan Ajar sebagai Acuan Pengembangan Modul Fisika Gelombang Bola dan Tabung," EduFisika, vol. 3, pp. 17-23, 2018.

[11] Y. Mutiarsih, S. Rakhmat and Y. Mulyadi, "Aplikasi Metode Reciprocal Teaching dalam Pembelajaran Menulis Teks Jurnalistik Bahasa Perancis Berbasis Kearifan Lokal," BARISTA, vol. 3, pp. 203-208, 2016.

[12] R. Yuliarti and C. Simonutti, "Peningkatan Kemampuan Bahasa Prancis Lisan Mahasiswa Prodi Bahasa dan Sastra Prancis melalui Tugas Pembuatan Video Visite Guidée," Jurnal Puitika, vol. 13, pp. 49-55, 2017.

[13] F. Hasanah and N. H. Saefullah, "Strategi Belajar Efektif bagi Pembelajar Pemula Bahasa Prancis di Madrasah Aliyah Negeri Model Babakan Ciwaringin MajalengkaCirebon," Dharmakarya, vol. 6, pp. 200-203, 2017.

[14] S. U. Putri, "Pengembangan Desain Blended Learning untuk Program Pelatihan Pendalaman Materi IPA Berbasis Kebutuhan Mahasiswa PGSD," Mimbar Sekolah Dasar, vol. 1, pp. 153-160, 2014. 
[15] Z. Hussin, S. Siraj, G. Darusalam and N. H. M. Salleh, "Kajian Model Blended Learning dalam Jurnal Terpilih: Satu Analisis Kandungan," JuKu: Jurnal Kurikulum \& Pengajaran Asia Pasifik, vol. 3, pp. 1-6, 2015.

[16] D. H. Brown, Teaching by Principle : An Interactive Approach to Language Pedagogy, New York: Pearson Education, Inc., 2001.

[17] C. d. L'Europe, Cadre européen commun de référence pour les langues: apprendre, enseigner, évaluer, Paris: Didier, 2001

[18] G. Vigner, Pratique d'écriture: apprendre à rédiger en langue étrangère, Paris: Hachette, 2013.

[19] C. Tagliante, l'Évaluation et le Cadre européen commun, Paris: CLE International, 2005.

[20] J. Bersin, The Blended Learning Book: Best Practices, Proven Methodologies, and Lessons Learned, San Fransisco: Pfeiffer, 2004.

[21] Husamah, Pembelajaran Bauran (Blended Learning), Malang: Prestasi Pustaka, 2014.

[22] M. Syaefudin and A. Yulianto, Strategi Pembelajaran Bahasa Asing, Semarang: Unnes Semarang Press, 2012.

[23] L. Giroux, "La place et le(s) rôle(s) de la langue maternelle des apprenants en cours de langue étrangère," Synergies France, vol. 10, pp. 55-68, 2016.

[24] H. WANG, "Les apports de l'apprentissage coopératif en production écrite. Une expérimentation pédagogique avec un public chinois," Synergies France, vol. 11, pp. 103117,2017 